REGARDS

SUR LEECONOMIE ALLEMANDE

BULLETIN ECONOMIQUE DU CRAC

\section{Regards sur l'économie allemande}

Bulletin économique du CIRAC

$92 \mid 2009$

Varia

\title{
Unité allemande : une réalité largement ressentie
}

Isabelle Bourgeois

\section{OpenEdition}

Journals

Édition électronique

URL : https://journals.openedition.org/rea/3773

DOI : 10.4000/rea.3773

ISBN : 978-2-8218-0880-5

ISSN : 1965-0787

Éditeur

CIRAC

Édition imprimée

Date de publication : 1 juillet 2009

Pagination : 36

ISSN : 1156-8992

Référence électronique

Isabelle Bourgeois, "Unité allemande : une réalité largement ressentie », Regards sur l'économie allemande [En ligne], 92 I juillet 2009, mis en ligne le 01 juillet 2011, consulté le 28 juin 2022. URL http://journals.openedition.org/rea/3773 ; DOI : https://doi.org/10.4000/rea.3773

Ce document a été généré automatiquement le 29 septembre 2020

(C) CIRAC 


\title{
Unité allemande : une réalité largement ressentie
}

\author{
Isabelle Bourgeois
}

1 Près de 19 ans après l'Unité, $62 \%$ des Allemands pensent « qu'il n'y a plus aucune raison de se focaliser dans les débats sur des différences entre l'est et l'ouest. Bien sûr, il y a encore des problèmes, mais dans l'ensemble, les choses sont bien telles qu'elles sont ". C'est ce qu'il ressort d'un sondage représentatif effectué courant avril par l'Institut für Demoskopie d'Allensbach (sondage IfD $\left.n^{\circ} 10036\right)$. Les moins satisfaits sont aujourd'hui les Allemands de l'est (à $47 \%$ seulement; ouest : 66\%), l'écart s'étant depuis peu creusé à nouveau. Le discours électoraliste de la nouvelle gauche allemande recréée sur les ruines du parti SED (Die Linke), comme la multiplication des débats médiatiques sur la RDA en cette période commémorative pourraient bien ne pas être étrangers à ce regain d'« Ostalgie »... (IB)

\section{INDEX}

Mots-clés : unité allemande, réunification, société, identité nationale, Ostalgie 